\title{
Recruitment and Training of Employees Vishal Mega Mart Patna
}

\author{
P. Karthikeyan, Gowtham Aashirvad, M. Ajith
}

\begin{abstract}
The title of the project is " RECUIRTMENT AND TRAINING OF EMPLYOEES ATVISHAL MEGA MART ABIDS HYDERABAD" and is solely an internal analysis of the organization. The project was done in order to identify the effectiveness of the employee satisfaction level towards the recruitment and training process happening in the organization.
\end{abstract}

\section{INTRODUCTION}

The effective was measured wholly based on the opinion of the employees and workers in all level, it is also analyzed with various statistically statement and studied about the sources [1-3].

The study was carried out because the management wanted to find out the various factors that affected the benefits of the training for the employees. Organization is providing training programs and seminars, and various other development programs also. With reference to those details a structured questionnaire was prepared. Which was used to get response from a sample of 250 employees?

In this study Descriptive Research Design was used and Convenience Sampling Method was used as the sampling procedure, and Data obtained were statistically analyzed using Chi- Square test and Kolmogrov Smirnov D Test and Kendall's Concordance test. The analysis and interpretations helps to identity the findings and suggestion of the workers.

Enrollment frames the main stage in the process which proceeds with determination and stops with the position of the up-and-comer. It is the subsequent stage in the acquisition work the first being the labor arranging [4-7].

Enrollment has been viewed as the most significant capacity of faculty organization, in light of the fact that except if the correct kind of individuals are procured, even the best plans, association graphs and control frameworks would not do much good. Enlistment both as 'positive' and 'negative' action [8-11].

. "It is a process of searching for prospective employees and stimulating and encouraging them to apply for jobs to increase the 'hiring ratio', i.e., the number of applicants for a job. Selection, on the other hand tends to be negative because it rejects a good member of who apply, leaving only the best to be hired" $[12,13]$.

Revised Manuscript Received on July 22, 2019.

P. Karthikeyan, Department of Management Studies, Bharath Institute of Higher Education and Research, Chennai, Tamilnadu, India

Gowtham Aashirvad, Department of Management Studies, Bharath Institute of Higher Education and Research, Chennai, Tamilnadu, India

M. Ajith, Department of Management Studies, Bharath Institute of Higher Education and Research, Chennai, Tamilnadu, India

\section{FACTORS AFFECTING RECRUITMENT}

All associations, regardless of whether enormous or little, do take part in enrolling action, however not to a similar degree [14-17]. This contrasts with:

- The size of the association.

- The work conditions in the network where the association is found.

- The impact of the past enlisting endeavors which demonstrate the association's capacity to find and keep great performing individuals.

- Working conditions and compensation and arrangement for assistance offered by the association which may impact turnover and require future enlisting.

- The pace of development of association.

- The level of regularity of activities and future extension and creation programs.

- Cultural, monetary and lawful components, and so forth.

\section{OBJECTIVES OF RECRUITMENT}

The objectives of recruitment are:

- To draw in individuals with multi-dimensional abilities and experience that suits the present and future authoritative systems.

- To accept untouchables with another point of view to lead the organization.

- To imbue new blood at all degrees of the association.

- To build up the authoritative culture that draws in able individuals to the organization.

- To search or head chase/head pocket individuals whose aptitudes fit the organization's qualities.

- To devise technique for surveying mental attributes.

- To search out non-traditional advancement grounds of ability.

- To look for ability universally and not simply inside the organization.

- To structure passage pay that contends on quality however not on quantum.

- To envision and discover individuals for places that does not exist yet 


\section{METHODS OR TECHNIQUES OF RECRUITMENT}

Enrollment strategies are the methods or media by which the board contacts forthcoming representatives or give vital data or trades thoughts so as to invigorate them to apply for employments. The executives utilizes various procedures to invigorate inner and outside applicants. These methods are delegated conventional and present day strategies [18, 19].

\section{A. Modern techniques}

A. Scouting: Scouting means sending the portrayal of the associations to different wellsprings of enlistment with the end goal of influencing or animating the possibility to apply for occupations. The delegates give data about the organization and trade data and thoughts and explain the questions of the competitor [20].

B.Salary and advantages: Companies invigorates the forthcoming competitors by offering higher level compensation, more advantages, speedy advancements and so on [21].

C.ESOPs: Companies as of late began invigorating the representatives by offering stock possession to the workers through their EMPLOEES STOCK OWNERSHIP PROGRAMMES(EOSPs) [22].

\section{TRAINING}

Preparing is a procedure of learning a grouping of customized conduct. It is an utilization of learning and gives individuals a familiarity with the standards and methods to control their conduct. It endeavors to improve their presentation on the present place of employment or set them up for the expected if.

Preparing a learning knowledge in that it looks for a moderately lasting change in a person that will improve his/her capacity to perform at work [23,24].

Representative preparing is where individuals learn abilities, information, characteristics and conduct required so as to play out their activity viably. To be exact, powerful orderly preparing might be characterized as wanting to give individuals a change to learn, to accomplish the outcomes that activity requests.

Five main areas in which training can be operated can be derived from the above definitions. These areas are.

Skills: A skill is physical act reaction skills can be improved through continuous efforts on particular work.

Experience: Experience is the aftereffect of partaking the utilization of learning, abilities and methods over some stretch of time and regularly in number of various circumstances, one of the preparation official's assignments is to orchestrate involvement of students on a sorted out premise. Regularly this can be accomplished by methods for occupation revolution, and now and again by trade of faculty conduct between organizations $[25,26]$.

\section{A. Need for training}

The requirement for preparing and improvement of workers on a proceeding with premise in sorted out parts of human action is never again a matter of discussion. The need has been perceived as a basic movement not just of the executives out in the open and private divisions yet in addition of worker's guilds, scholarly organizations, proficient bodies and the different offices and offices of the legislature. A portion of the conditions that have prompted the familiarity with the significance of preparing and advancement exercises in the associations in the 1960 period in India are

o Sub ideal execution of associations openly, government and private parts.

o The regularly expanding hole among arranging and usage of undertakings.

o Technological change requiring securing of new aptitudes.

o Qualitatively change as professionalization of administrative staff and laborers.

o Increased un-convictions and complexities in the earth requiring adaptable and versatile reactions [27, 28].

\section{TRAINING METHODS AND TECHNIQUES}

\section{A. On the activity training(OJT)}

Hands on preparing are the most generally utilized and acknowledged, and the most vital technique for preparing workers in the aptitudes fundamental for worthy for occupation execution. Under this strategy the specialist is prepared at work at his work place [29].

i. Job guidance training(JIT)

The activity guidance preparing is a type of individual guidance by managers and is like training. The method is proper for allegation or improvement of engines abilities and normal and dull activities

\section{ii. Coaching}

Instructing is again hands on preparing of individual by the chief in the region of explicitly characterized errands. This method is increasingly proper for direction of new representative and for helping distraught workers to learn explicit employments.

\section{iii. Simulation}

Recreation is a preparation procedure where the real conditions experienced on a vocation. The business games and vestibule preparing are the instances of recreation preparing.

\section{B. Off the job training}

\section{Lectures}

Talk is by a long shot the most generally utilized method of preparing included addressing enormous number of students as a rule from arranged notes. This is progressively fitting in circumstances where same data is 
required to be shared to enormous crowd and where there is no time for increasingly participative technique [30].

- Conference

The gathering technique is utilized to enable representatives to build up some critical thinking aptitudes. Gathering discourses and gatherings are the two regular procedures frequently utilized in the associations.

- Laboratory preparing

Research facility preparing, regularly called affectability preparing or T-gathering, depends on the standards of gathering elements and is broadly utilized as an apparatus for teaching camaraderie among representatives.

\section{- Role playing}

Pretending is utilized in pushing the learners to diagonise human relations issues, to create understanding through top to bottom investigation of issues.

\section{- Evaluation of preparing}

Assessment of preparing project includes a correlation of what was practiced during the preparation progamme with what was planned. The assessment must be straightforwardly identified with the first preparing system objectives. The assessment of program is made based on some pre-decided estimated of the abilities, learning or frame of mind of the student.activities [31].

\section{NEED FOR THE STUDY}

To provide an accessible path for each worker and to encourage the continued growth of their talents and abilities. To ensure that each team is interested in the organization's private goals and goals of emplyoement.

Training is primarily for improving the performance of a person on his current job, it is necessary to collect and store the following date which can be made use of it in identification of training needs:

- Job description of individuals as perceived by them and their superiors against the individual's profile.

- Job performance review i.e. level of performance achieved by individual measured against both job content and agreed personal objectives.

- Potential of individuals to grow within the organization keeping in view the growth rate of the organization and its future objectives.

- Managerial ability and traits of individual which can contribute towards performance on the job.

\section{OBJECTIVES OF THE STUDY}

The basic objectives of training are as follows:

1) Improve the efficiency of the current coaching programs with regard to recognized issues.

2) To identify training needs of the employees in the division.

3) Involve line executives in the teaching feature by launching the participatory leadership method.

\section{QUESTIONNARIE DESIGN}

The structured questionnaire is prepared taking into consideration of Administrative arrangements, duration of the Training Programme, evaluation of training programme, regarding material, overall schedule, major benefits, Audio-visual Aids, relevant exercises, recommendation of training programmes to others, implementation of learnt things during the training programme.

\section{DATA COLLECTION}

Information alludes to data or actualities. It incorporates numerical figures, non-numerical figures, expressive realities, and subjective data. The errand of information accumulation starts after an exploration issue has been characterized and plan has been chosen.

The idea of the information is both essential and auxiliary information.

Primary Data

The essential information are those that are gathered through poll and direct close to home meeting. The poll was confined in such a way to acquire right data, evaluated appropriately from the respondents.

Secondary Data

Auxiliary information has been gathered through oral correspondence. Optional information about the organization profile and subtleties were gathered from the organization website.

\section{TIME OF STUDY}

The investigation was under taken for a multi month during fifteenth April 2008 - 30th April2008. During the period the accompanying .

- Questionnaire were pre-tried.

- Objectives were set and survey was finished.

- Data were gathered and recorded.

- Data were investigated and translated.

- Reports were produced.

\section{SAMPLING SIZE}

Because of time and asset limitation the example size has been taken as 250 for Consultation with the organization guide and task manage.

\section{PILOT SURVEY}

A pilot review with 25 tests from representatives was led for testing the legitimacy of the inquiries. It was discovered 
that there was no requirement for changes in the poll and thus a similar survey was utilized for definite review moreover.

\section{RESULTS AND DISCUSSION}

- Convenience testing has its very own time confinement in light of the fact that the odds of right people on being chosen can be less.

- Time is the primary requirement as it is hard to meet every one of the workers of the association inside a brief period.

Cost is also the main constrain as this research involves massive amount for the purpose of preparing the report.

The information, after gathering must be handled and investigated as per the layout set down for the reason at time of building up the examination plan. This is basic for a logical report and for guaranteeing that we have every single applicable datum for some mulled over examinations and investigation. Specialized handling suggests altering, coding, groupings and organization of gathered information with the goal that they are agreeable to investigation [32, 33].

\section{Summary OF Findings}

We need to state both the general findings of the report which are not quantifiable and the findings that we got on the basis of statistical tools.

Suggestions and Recommendations

By the end of the research we need to give our suggestions and recommendations to the company in which we have done the projects. We need to point out their faults as well as give the solutions to the problems that have been identified.

\section{CONCLUSION}

Finally we need to conclude the project by given a very short summary of the same.

\section{REFERENCES}

1. BharthVajan R., Ramachandran S.,Psychographic dimensions of training,2016,International Journal of Pharmacy and Technology,V-8,I-4,P-23727-23729

2. Balakrishnan P., Bharthvajan R.,A study on human resource planning in hospitals in Chennai City,2014,International Journal of Applied Engineering Research,V-9,I-22,P-7503-7507

3. Priyadarsini P., Bharthvajan R.,Role of emotional intelligence training programme in reducing the stress of the nurses,2014,International Journal of Applied Engineering Research,V-9,I-22,P-7411-7421

4. Kerinab Beenu G., Bharthvajan R.,Empirical analysis on the cosmetic buying behavior of young women in South India,2014,International Journal of Applied Engineering Research,V-9,I-22,P-7361-7366

5. Balakrishnan P., Bharthvajan R.,Whistling in the wind,2014,International Journal of Applied Engineering Research,V-9,I-22,P-7586-7593

6. Krishnan B., Peter M.,Health hazards of Indian Bpo employee-an alarming issue,2014,International Journal of Applied Engineering Research,V-9,I-22,P-7336-7341

7. Kerinab Beenu G.H., Peter M.,Role of insurance in economic development,2014,International Journal of Applied Engineering Research,V-9,I-22,P-7532-7539

8. Balakrishnan P., Peter M., Priyadarsini P.,Efficiency of safety measures for wellbeing of employees in manufacturing industry,2014,International Journal of Applied Engineering Research,V-9,I-22,P-7376-7382
9. Anbarasi M., Praveen Kumar S.,Online sales promotions of herbal products and its effectiveness towards tanisha.com,2019,Indian Journal of Public Health Research and Development,V-10,I-1,P-195-200

10. Anbarasi M., Praveen Kumar S.,Various online marketing and promotions strategies to improve the validation towards the organic products in the pharmaceutical sectors,2019,Indian Journal of Public Health Research and Development,V-10,I-1,P-263-269

11. Loganathan R., Praveen Kumar S.,Grievance handling a key factor for solving issues of employees in an organization,2014,International Journal of Applied Engineering Research,V-9,I-22,P-7483-7491

12. Loganathan R., Praveen Kumar S.,Study on preference of private label brands in super and Hypermarkets,2014,International Journal of Applied Engineering Research,V-9,I-22,P-7327-7335

13. Smitha M., Praveen Kumar S.,Understanding stress and its managementamong the nurses in Chennai city,2014,International Journal of Applied Engineering Research,V-9,I-22,P-7560-7565

14. Kerinab Beenu G.H., Praveen Kumar S.,A study on the investment behavior of Chennai investors in mutual fund schemes,2014,International Journal of Applied Engineering Research,V-9,I-22,P-7520-7525

15. Loganathan R., Praveen Kumar S.,Retention strategies key for organizational productivity,2014,International Journal of Applied Engineering Research,V-9,I-22,P-7443-7447

16. Pavithra J., Ganesan M., Brindha G.,State wise analysis of microfinance sector in India,2016,International Journal of Pharmacy and Technology,V-8,I-4,P-23417-23432

17. Pavithra J., Ganesan M.,A comparative study on microfinance in India and abroad,2016,International Journal of Applied Business and Economic Research,V-14,I-8,P-5471-5476

18. Pavithra J., Ganesan M.,A study on awareness and impact of micro-financial schemes,2016, International Journal of Applied Business and Economic Research,V-14,I-8,P-5449-5460

19. Senthilmurugan P., Pavithra J.,Consumer preference towards organised retailing with reference to Big Bazaar,2014,International Journal of Applied Engineering Research,V-9,I-22,P-7469-7475

20. Senthilmurugan P., Pavithra J.,Implication of social media marketing in growing healthcare industry,2014,International Journal of Applied Engineering Research,V-9,I-22,P-7448-7456

21. Loganathan R., Pavithra J.,Consumer perception towards private label brand over other brands in super markets and hypermarkets,2014,International Journal of Applied Engineering Research,V-9,I-22,P-7355-7360

22. Kerinab Beenu G., Pavithra J.,Tradeâ€"off between liquidity and profitability in logistics industry,2014,International Journal of Applied Engineering Research,V-9,I-22,P-7398-7401

23. Kerinab Beenu G., Pavithra J.,A study on the prospective consumerâ€ $\mathfrak{T M}_{\mathrm{S}}$ perception towards utility cars in Chennai city,2014,International Journal of Applied Engineering Research,V-9,I-22,P-7526-7531

24. Pavithra J., Dilli Babu P., Ambuli T.V.,A study on budgetary control at Maruti Service Masters, Chennai,2014,International Journal of Applied Business and Economic Research,V-12,I-2,P-151-161

25. Pavithra J., Dilli Babu P., Ambuli T.V.,A study on customer satisfaction of retro Garments Pvt Ltd, Chennai,2014,International Journal of Applied Business and Economic Research,V-12,I-2,P-381-391

26. Kerinab Beenu G.H., Pavithra J., Senthilmurugan P.,A study on the influence of promotional activities for TATA ARIA among consumers in Chennai,2014,International Journal of Applied Engineering Research,V-9,I-22,P-7572-7578

27. Vijayaragavan S.P.,An investigative expert that's general FBG sensors,International Journal of Mechanical Engineering and Technology,V-8,I-8,PP-1500-1505,Y-2017

28. Vijayaragavan S.P.,Equalization routing protocol for Wi-Fi sensor strategy,International Journal of Mechanical Engineering and Technology,V-8,I-8,PP-1662-1666,Y-2017

29. Karthik B., Kiran Kumar T.V.U., Vijayaragavan P., Bharath Kumaran E.,Design of a digital PLL using 0.35 $\hat{\mathrm{I}}^{1 / 4 \mathrm{~m}}$ CMOS technology,Middle East Journal of Scientific Research,V-18,I-12,PP-1803-1806,Y-2013

30. Kanniga E., Selvaramarathnam K., Sundararajan M.,Kandigital bike operating system,Middle - East Journal of Scientific Research,V

31. Jasmin M., Vigneshwaran T., Beulah Hemalatha S.,Design of power aware on chip embedded memory based FSM encoding in FPGA,International Journal of Applied Engineering Research,V-10,I-2,PP-4487-4496,Y-2015

32. Jasmin M.,Optimization techniques for low power VLSI circuits,Middle East Journal of Scientific Research,V-20,I-9,PP-1082-1087,Y-2014

33. Jasmin M., Vigneswaran T.,Fuzzy controller for error control of on - Chip communication,2017 International Conference on Algorithms, Methodology, Models and Applications in Emerging Technologies, ICAMMAET 


\section{AUTHORS PROFILE}

P. Karthikeyan, Student, Department of Management Studies, Bharath Institute of Higher Education and Research, Chennai, India

Gowtham Aashirvad, Associate Professor, Departmen of Management Studies, Bharath Institute of Higher Education and Research, Chennai, India

M. Ajith, Student, Department of Management Studies, Bharath Institute of Higher Education and Research, Chennai, India 